\title{
INTEGRATION OF MECHANICAL AND CULTURAL CONTROL TREATMENTS TO MANAGE INVASIVE SHRUB Chromolaena odorata AND OTHER WEEDS UNDER DROUGHT CONDITIONS IN PASTURE AREA
}

\author{
M. Rusdy ${ }^{1}$, R.Sjahril ${ }^{2}$, M. Riadi ${ }^{2}$ and Budiman ${ }^{1}$ \\ ${ }^{1}$ Faculty of Animal Husbandry, Hasanuddin. University, \\ Jl. PerintisKemerdekaan Km. 10 Makassar - Indonesia \\ ${ }^{2}$ Faculty of Agriculture, Hasanuddin University, \\ Jl. PerintisKemerdekaan Km. 10 Makassar - Indonesia \\ Corresponding E-mail:muhrusdy79@yahoo.co.id
}

Received December 22, 2012; Accepted February 18, 2013

\begin{abstract}
ABSTRAK
Suatu penelitian lapangan telah dilakukan pada padang penggembalaan yang didominasi Chromolaena odorata dengan tujuan untuk mengevaluasi efektifitas pengontrolan secara mekanik dan kultural yang terintegrasi terhadap penekanan pertumbuhan gulma dan menentukan komposisi botanis spesies tumbuhan setelah perlakuan dimulai. Perlakuan penelitian adalah T1: pembabatan Chromolaena tiap bulan, T2: penggalian Chromolaena dan dibiarkan mengering (dijadikan mulsa), T3: penggalian Chromolaena yang diikuti dengan pembakaran, T4: penggalian Chromolaena diikuti dengan pembakaran dan penanaman Centrosema pubescens dan T5: penggalian Chromolaena diikuti dengan pembakaran dan penanaman Brachiaria decumbens. Hasil penelitian menunjukkan bahwa pada kondisi kekeringan, penggalian Chromolaena sangat efektif untuk menekan pertumbuhan kembali Chromolaena tetapi tidak efektif terhadap gulma lainnya. Dari semua perlakuan, penanaman Brachiaria decumbens merupakan metoda yang paling efektif dan pembabatan Chromolaena tiap bulan merupakan metoda yang paling tidak efektif untuk menekan pertumbuhan gulma. Komposisi botanis spesies berubah sesuai dengan perlakuan. Stachytarpheta jamaicensis dan Chromolaena odorata merupakan spesies yang dominan pada petak dimana Chromolaena dipotong tiap bulan dan Stachytarpheta jamaicensis dan Calopogonium muconoides dominan pada petak yang diberi mulsa sedangkan Mimosa pudica, Brahiaria decumbens dan Centrosema pubescens merupakan spesies yang dominan pada petak yang dibakar.

Kata kunci: Chromolaena odorata, komposisi botanis, penekanan gulma, pengontrolan mekanik dan kultural
\end{abstract}

\begin{abstract}
A field experiment was conducted on Chromolaena odorata dominated pasture with the objectives of evaluating efficacy of integrated of mechanical and cultural control on weed suppression and determining botanical composition of plant species after treatment started. The treatments were, T1 slashing of Chromolaena every month, T2 digging up of Chromolanea, and exposed to dry (mulching), T3 digging up of Chromolaena followed by burning, T4 digging up of Chromolaena followed by burning and sowing with Centrosema pubescens and T5 digging up of Chromolaena followed by burning and planting with Brachiaria decumbens. Results of experiment showed that under drought conditions, digging up Chromolaena was very effective in suppressing regrowth of Chromolaena but it was not effective to other weeds. Among treatments, digging out of Chromolaena followed by burning and planting with Brachiaria decumbens was the most effective and slashing of Chromolaena every month was the least effective in suppressing weeds. Botanical composition was shifted with treatments. Stachytarpheta jamaicensis and Chromolaena were the dominant species in monthly slashed Chromolaena plots, Stachytarpheta and Calopogonium muconoides were the dominant species in mulched plots while Mimosa pudica, Brachiaria and Centrosema were the dominant species in burnt plots.
\end{abstract}

Keywords: botanical composition, Chromolaena, mechanical and cultural controls, weed suppression. 


\section{INTRODUCTION}

Chromolaena odorata (L.) King and $\mathrm{H}$. Robinson (hereafter is called Chromolaena), known in South Sulawesi as jonga-jonga, meaning deer weed, is a major invasive weed of pasture and plantation crops in many countries in Africa, South and Southeast Asia and the Pacific. Chromolaena has become one of the worst terrestrial invasive plants in humid tropics and subtropics overly the past century (Gautier, 1992).

Chromolaena can grow rapidly and form infestation and can affect agriculture, pasture and biodiversity, as Chromolaena interferes with the functions of natural ecosystems. It can be very invasive, forming impenetrable thickets in open areas such as pastures. It can suppress pasture plants by competing nutrients and water, overshading and its allelopathic effect lowering productivity of desirable forage species with a concomitant loss of livestock production. Chromolaena leaves, especially the young ones, are toxic to animals due to high levels of nitrate (5 -6 times above toxic level) (Sajise, 1974).

Control of Chromolaena is difficult due to its ability to thrive in a wide variety of soils, rapid attainment of reproductive maturity, large production of easily dispersed seed, a significant proportion of seed persisting in the soil more than one year and strong ability to resprout after burning (Witkowsky and Wilson, 2001). Mechanical control is one of the common methods used for control of Chromolaena in many countries. Mechanical controls include labor intensive hand weeding, slashing, digging and burning. In conventional areas, the initial slashing operation is followed by digging and sometimes burning. Slashing and burning reduces the standing biomass but regrowth will occur from rootstock , usually more profusely. Cultural controls include the use of mulch and various fast growing forages and other plants, still have been rarely used in controlling of Chromolaena.

In Maiwa pasture, more than $50 \%$ of area has been covered by Chromolaena that severely reduced grazing area. The owner has spent much money on slashing, digging and burning Chromolaena without much of success. This is because mechanical control requires repeated follow operation to achieve complete eradication. Notwithstanding these restrains, this method is still widely used, because a plentiful unskilled cheap labor is available.

In recent years, investigation is in the progress in examining the use of integrated mechanical, chemical and cultural control methods for controlling Chromolaena. The present experiment was conducted in Chromolaena dominated pasture with the purpose of evaluating the efficacy of mechanical control and integrated of mechanical and cultural control methods in suppressing the regrowth of Chromolaena and other weeds and determining botanical composition of plant species during dry season.

\section{MATERIALS AND METHODS}

This experiment was conducted during dry season in a pasture owned by Faculty of Animal Husbandry Hasanuddin University located at Maiwa, Enrekang Regency South Sulawesi, from July to November 2012. The site was heavily infested by combinations of Chromolaena odorata, Stachytarpheta jamaicensis, Borreria sp and some other weeds and herbage species. There were five mechanical and integrated mechanical and cultural control treatments i.e. T1 slashing of Chromolaena every month at $10 \mathrm{~cm}$ above soil level, T2 digging up of Chromolaena and exposed to dry (mulching), T3 digging up of Chromolaena followed by controlled burning, T4 digging up of Chromoalena followed by burning and sowing with Centrosema pubescens, and T5 digging up of Chromolaena followed by burning and planting with Brachiaria decumbens. The plants were harvested at one, two and three months after treatment imposed. The seeds of Centrosema pubescens and tillers of Brachiaria decumbens were sown into plots immediately after burning. Super Phosphate 36 (SP36) and urea fertilizer at the rates of $40 \mathrm{~kg} \mathrm{P}_{2} \mathrm{O}_{5}$ and $46 \mathrm{~kg} \mathrm{~N} / \mathrm{ha}$, respectively were applied to Centrosema pubescent sown plot at the time of sowing, while urea was applied to Brachiaria decumbens planted plots two weeks after planting.

Plot sizes were 5.0 x $5.0 \mathrm{~m}$ and a $1.0 \mathrm{~m}$ space between plots was allotted to prevent treatment effects of one plot to other plots. The study area was fenced off using barbed wire and a height of $2.0 \mathrm{~m}$ was maintained all around the study area, to keep out of animals and unauthorized persons. The fenced area measured was $50 \times 40 \mathrm{~m}$. The area of $100 \mathrm{~m}$ wide outside of fences was ring weeded using motorized brush cutter to prevent flowering of Chromolaena and accidental burning. 
The efficacy of treatment was assessed on the basis of dry matter weight of Chromolaena and other weeds regrowth sampled at one, two and three months after treatment. The less dry matter of weeds yielded, the high were their efficacy. Sample of regrowth was taken from cutting of plants at different places at $3 \mathrm{~cm}$ above soil surface in quadrants measuring $1 \mathrm{~m} \mathrm{x} 1 \mathrm{~m}$. To determine dry matter contents, the fresh samples obtained were dried in oven at $80^{\circ} \mathrm{C}$ for 72 hours and weighted.

\section{Statistical Analysis}

This experiment was conducted using a split plot in time design with five integrated mechanical and cultural control treatments as main plot and three times of cutting as sub plot with three replications. All data were subjected to analysis of variance and probability value $<0.05$ is considered significant. Difference among each treatment were further analyzed using least significant difference method.

\section{RESULTS AND DISCUSSION}

\section{Efficacy of Treatments}

The seeds of plants in the soil were continued to germinate and the slashed plants were continued to regrow after treatments imposed. The dry matter yields of weeds of each treatment are shown in Table 1.

Table 1 shows that for three months after treatment, dry matter yield of Chromolaena as influenced by digging up of Chromolaena combined with other treatments was negligible. This indicated that under drought conditions, digging up is the most effective in controlling regrowth of Chromolaena, but not to other weeds. The negligible seed germination and dry matter yield of Chromolaena indicated that during dry season, there was no seed and seedling of Chromolaena that germinated and grew in the soil, meanwhile other weed seeds continued to germinate and grow. It seems that there was still large viable seed population in experimental site that had been covered by dense stand of Chromolaena for over ten years. The negligible seed germination of Chromolaena in this study may be attributed to the low available water in the soil as most of this experiment occur in heavy drought in which total rainfall during the study (August to November) was only $259 \mathrm{~mm}$.

The low seed germination of Chromolaena seed during dry season was also stated by
McFayden (2003) and Agarwala and Das (2012), although some seeds appeared to remain dormant for several years (Jeffery, 2010). The low density of seedling emergence of Chromolaena experiencing severe drought was reported by Fittschen (2006) that in dry areas during three years of his study, seedling density of Chromolaenawere only $0.5,0.56$ and 1.06 per 5 $\mathrm{m}^{2}$ in the three sites, respectively.

The control of Chromolaena by digging up is very effective under drought conditions but it was an on going process as new seeds continue to blow in from distant infestation. If these seeds and seed bank in the soil get enough available moisture and light, these seeds can germinate and grow rapidly.

Across the digging out treatments, burning of Chromolaena followed by planting with Brachairia decumbens was significantly more effective in suppressing weeds than sowing with Centrosema pubescens or burnt only treatment (Table 1). The higher efficacy of Brachiaria than that of Centrosema in suppressing weeds may be attributed to the higher of dry matter yield and covering ability of Brachiaria than those of Centrosema. This could be due to vigorous nature of Brachiaria growth and its ability to extract growth resources from the soil. Shelton (2012) stated that when established, Brachiaria decumbens will suppress weed effectively and within three months, a complete ground cover could be obtained. In this experiment, until the end of study a complete cover of Brachiaria decumbens was not attained, however, dry matter yield of this grass steadily out yielded of weeds (Table 2). This was in parallel with report of Renrun and Xaejun (2012) that in the first two years of establishment, Brachiaria decumbens in pasture had effectively prevented germination of the seeds and seedlings growth of Chromolaena plus other weeds and in the third year virtually no Chromolaena was noted in the pasture.

Although sowing with Centrosema was less effective than planting with Brachiaria, however sowing with Centrosema was more effective than burning only in suppressing weeds, although it was not significantly different (Table 1). This indicated that to gain control of weeds form burnt vegetation, the vigorous trailing and twining Centrosema can be used, as this plant can cover the ground and vegetation well and stop weeds growing beneath them by competing with nutrients, space and light.

In this experiment, burning was not effective 
Table 1. Dry Matter Yield of Chromolaena and Other Weeds (g/plot) after Treatment

\begin{tabular}{|c|c|c|c|c|c|}
\hline \multirow{2}{*}{ Treatmnt } & \multirow{2}{*}{ Plan } & \multicolumn{3}{|c|}{ Month after Treatment } & \multirow{2}{*}{ Mean } \\
\hline & & One & Two & Three & \\
\hline \multirow[t]{3}{*}{$\mathrm{T} 1$} & Cromolaena odorata & 353.33 & 1370.00 & 393.33 & 705.55 \\
\hline & Other weeds & 923.33 & 4866.65 & 2308.34 & 2699.44 \\
\hline & Total weeds & 1276.66 & 6236.65 & 2701.67 & $3404.99^{c}$ \\
\hline \multirow[t]{3}{*}{$\mathrm{T} 2$} & Cromolaena odorata & 0.00 & 0.00 & 0.00 & 0.00 \\
\hline & Other weeds & 281.65 & 2311.65 & 1950.00 & 2203.00 \\
\hline & Total weeds & 281.65 & 2311.65 & 1950.00 & $1514.43^{b}$ \\
\hline \multirow[t]{3}{*}{$\mathrm{T} 3$} & Cromolaena odorata & 0.00 & 0.00 & 0.00 & 0.00 \\
\hline & Other weeds & 550.00 & 3195.00 & 2865.00 & 2203.33 \\
\hline & Total weeds & 550.00 & 3195.00 & 2865.00 & $2203.33^{b}$ \\
\hline \multirow[t]{3}{*}{$\mathrm{T} 4$} & Cromolaena odorata & 0.00 & 0.00 & 0.00 & 0.00 \\
\hline & Other weeds & 560.00 & 2188.35 & 2116.67 & 1621.67 \\
\hline & Total weeds & 560.00 & 2188.35 & 2166.67 & $1621.67^{b}$ \\
\hline \multirow[t]{4}{*}{$\mathrm{T} 5$} & Cromolaena odorata & 0.00 & 0.00 & 0.00 & 0.00 \\
\hline & Other weeds & 308.35 & 836.67 & 1065.00 & 736.62 \\
\hline & Total weeds & 308.35 & 836.67 & 1065.00 & $736.62^{\mathrm{a}}$ \\
\hline & Mean & $555.00^{\mathrm{a}}$ & $2953.66^{b}$ & $2149.67^{b}$ & \\
\hline
\end{tabular}

Means of total weed sharing with different letter are significantly different $(\mathrm{P}<0.05)$

in suppressing the regrowth of weeds. This result is not agree with Ossom et al. (2007) in Swaziland that planned and controlled use of fire was the most effective and beneficial in controlling Chromolaena and other weeds. Most Chromolaena seeds germinated at soil surface (Bhagirathet al., 2008) that may be killed by burning and presence much seed of Mimosa in the soil may be a causative factor for the low efficacy of burning in controlling weeds, as burning stimulated hard coat seed of Mimosa pudica.

Application of Chromolaena mulch was more effective in suppressing weeds than slashing of Chromolaena every month (Table 1). The differences in growth factor conditions might be a causative factor. The low light transmission in mulched plots probably reduced most plant growth in study area, while the higher light intensity in slashed plots enhanced sun plant growth that probably comprises most of plants in the area.

\section{Botanical Composition}

Shift in botanical compositions as influenced by treatments are shown in Table 2 . There were 32 species of weeds and herbage recorded in experimental site. About $80 \%$ of the total plants comprised of only 10 species, namely, Chromolaena odorata, Stachytarpheta jamaicensis, Mimosa pudica, Brachiaria decumbens, Calopogonium muconoides, Borreria laevis, Borreria latifolia, Borreria ocymoides, Axonopus compressus and Cynodon dactylon.

The botanical compositions of species were influenced by mechanical and cultural control treatments. In monthly slashed plots the dominant species were Chromolaena and Stahytarpheta and in mulched plots, the dominant species were Calopogonium muconoides and Stachytarpheta. In burnt plots, botanical composition of Stachytarpheta decreased and the dominant species was taken over by Mimosa pudica, Brachiaria decumbens and Centrosema pubescens (Table 2).

The high botanical composition of Chromolaena in slashed plots than that of mulched plots, undoubtedly attributed to the presence of this plant in slashed plots that quickly 
Table 2. The rank of Dominant Species Based on Dry Mater Yield (g/plot) Every Month after Treatment

\begin{tabular}{|c|c|c|c|c|c|c|}
\hline \multirow{3}{*}{$\begin{array}{c}\text { Treatment } \\
\qquad \mathrm{T} 1\end{array}$} & \multicolumn{6}{|c|}{ Month after treatment } \\
\hline & \multicolumn{2}{|l|}{ One } & \multicolumn{2}{|l|}{ two } & \multicolumn{2}{|c|}{ Three } \\
\hline & Cromolaena & 353.35 & Stachytarpheta & 1983.35 & Stachytarpheta & 1650.00 \\
\hline & Stachytarpheta & 345.00 & Cromolaena & 1370.00 & Borreriasp & 441.65 \\
\hline & Borreria sp & 195.00 & Borreria sp & 655.00 & Chromolaena & 393.35 \\
\hline & Herbage & 175.00 & Herbage & 443.35 & Herbage & 930.00 \\
\hline & Other weeds & 383.30 & Other weeds & 2228.30 & Other weeds & 610.02 \\
\hline & Total & 1451.65 & Total & 6679.95 & Total & 4025.00 \\
\hline \multirow[t]{6}{*}{$\mathrm{T} 2$} & Calopogonium & 790.00 & Stachytarpheta & 1451.65 & Stachytarpheta & 1365.35 \\
\hline & Stachytarpheta & 145.00 & Calopogonium & 740.00 & Calopogonium & 740.00 \\
\hline & Borreria sp & 83.35 & Borreria sp & 690.00 & Borreria sp & 183.35 \\
\hline & Total herbage & 875.00 & Total herbage & 1560.65 & Total herbage & 1658.70 \\
\hline & Other weeds & 53.30 & Other weeds & 120.00 & Other weeds & 401.30 \\
\hline & Total & 1071.65 & Total & 3146.65 & Total & 2983.35 \\
\hline \multirow[t]{6}{*}{$\mathrm{T} 3$} & Mimosa & 218.35 & Mimosa & 1803.35 & Mimosa & 1420.00 \\
\hline & Stachytarpheta & 180.00 & Sinedrella & 561.33 & Stachytarpheta & 396.65 \\
\hline & Borreria sp & 128.35 & Stachytarpheta & 541.65 & Sinedrella & 303.35 \\
\hline & Herbage & 131.65 & Herbage & 233.35 & Herbage & 153.35 \\
\hline & Other weeds & 23.30 & Other weeds & 288.67 & Other weeds & 565.00 \\
\hline & Total & 681.65 & Total & 3428.35 & Total & 2838.35 \\
\hline \multirow[t]{7}{*}{$\mathrm{T} 4$} & Mimosa & 286.65 & Mimosa & 1390.00 & Mimosa & 1416.65 \\
\hline & Centrosema & 215.00 & Centrosema & 875.00 & Centrosema & 395.00 \\
\hline & Borreria sp & 98.35 & Stachytarpheta & 438.35 & Stachytarpheta & 396.50 \\
\hline & Stachytarpheta & 58.35 & Borreria sp & 2546.65 & Total herbage & 206.20 \\
\hline & Total herbage & 213.30 & Total herbage & 1656.00 & Total herbage & 1622.85 \\
\hline & Other weeds & 111.65 & Other weeds & 156.65 & Other weeds & 156.85 \\
\hline & Total & 796.65 & Total & 3628.35 & Total & 2717.86 \\
\hline \multirow[t]{7}{*}{$\mathrm{T} 5$} & Brachiaria & 443.35 & Brachiaria & 3256.65 & Brachiaria & 4916.65 \\
\hline & Mimosa & 148.35 & Mimosa & 328.35 & Mimosa & 493.35 \\
\hline & Stachytarpheta & 76.65 & Borreria sp & 308.30 & Stachytarpheta & 168.35 \\
\hline & Borreria sp & 56.65 & Stachytarpheta & 160.00 & Borreria sp & 123.35 \\
\hline & Total herbage & 480.00 & Total herbage & 3516.65 & Total herbage & 5016.65 \\
\hline & Other weeds & 26.68 & Other weeds & 241.15 & Other weeds & 279.95 \\
\hline & Total & 751.68 & Total & 4554.45 & Total & 6081.65 \\
\hline
\end{tabular}

coppices because it was not dig out as occurred in mulched plots. The high botanical composition of Calopogonium in mulched plots indicated that this plant was more tolerant to Chromolaena mulching than under open conditions found in slashed plots. Application of Chromolaena mulch moderates soil temperature, improved soil physical conditions and adds available $\mathrm{N}, \mathrm{P}$ and $\mathrm{K}$ to the soil (Manjappa, 2010). These conditions may enhance the growth of Calopogonium that tolerate to to partial shade, adapted to wide range of soils and tolerate to moderate drought conditions (Addison and Congdon, 2001). The high botanical compositions of Stachytarpheta in both slashed and mulched plots indicated that this plant has a wider tolerance to open conditions than Calopogonium.

The botanical composition of Mimosa in 
burnt plot was high, indicating that burning stimulated germination and seedling growth of this plant. This is in line with report of Landsdale and Miller (1993) that germination of hard coat seeds of Mimosa can be stimulated by burning. Burning of Mimosa seeds can kill surface seeds but not buried seeds and may stimulate seeds germination due to removal of seed coat (de Menezes and Rossi, 2011) and seedling growth might be enhanced by absence of competing vegetation after burning (Paynter and Finlayson, 2003). In contrast, in this study the botanical composition of Stachytarpheta in burnt plots was lower than to that of unburnt plots. This may be attributed to killing much of Sachytarpheta seeds by burning as its seed germination and emergence was restricted to seeds planted at the soil surface that easily killed by burning (Diaz-Filho,1996).

Botanical compositions of plants varied with time (Table 2). In slashed plots, botanical composition of Chromolaena decreased over time; conversely, botanical composition of Stachytarpheta increased with time (Table 2). The same trend also found in mulched plots, botanical composition of Stachytarpheta increased with time, while botanical composition of Calopogonium decreased. The decrease in botanical composition of Chromolaena in slashed plots may be partly due to the reduced reserve carbohydrate levels in the roots and stump, as regrowth of plants depends total nonstructural carbohydrate reserve contents in the remaining plant parts after cutting (Garcia et al., 2001) while increasing botanical composition of Stachytarpheta in both plots may be due to higher its adaptability to different light intensity, wide range of soils and soil moisture conditions (Gilman, 2013).

In burnt and forage planted plots, botanical composition of Brachiaria increased with time, while botanical composition of Centrosema peaked at second cutting and then decreased. Besides, botanical composition of Centrosema always lower than that Mimosa pudica (Table 2). This indicated that Centroema was less suitable to control weeds than Brachiaria and this may be attributed to its lower growth rate and covering ability.

\section{CONCLUSION}

Under drought conditions, digging up of Chromolaena integrated with cultural control is very effective in controlling regrowth of
Chromolaena, but not to other weeds. In the long term, digging up of Chromolaena followed by burning and planting with the fast growing forage like Brachiaria decumbens probably to be the most promising method in controlling Chromolaena and other weeds in pasture area. Planting of burnt area with other fast growing forage species in pasture needs to be investigated to find more effective species to suppress the regrowth of Chromolaena.

\section{ACKNOWLEDGEMENTS}

The authors are thankful to Rector of Hasanuddin University for providing financial support, and Dean of Faculty of Animal Husbandry for permitting us to use Maiwa ranch as a site to carry out this experiment. Thanks also due to the local farmers for assisting during the field experiment.

\section{REFERENCES}

Addison, H. and R. Congdon. 2001. Legumes for Agroforestry Systems. Proceeding of the $10^{\text {th }}$ Australian Agronomy Conference, January 29-February 1, 2001, Hobart, Tasmania.

Agarwala, B.K., and J. Das. 2012. Weed host specificity of the Aphids: Aphid spiraeoli: Developmental and reproductive performance of Aphids in relation to plant growth and leaf chemical of the Siam weed, Chromolaena odorata. J. Insect Sci. 12:2430.

Bhagirath, S., Chauhan and D.E. Johnson, 2008. Germination ecology of two troublesome species of rainfed rice: Siam weed (Chromolaena odorata) and coat buttons (Tridax procumbens. Weed Sci. 56:567-573.

de Menezes, L.C.C.R., and M.N. Rossi. 2011. A study with plant inhabiting non-fire prone areas. Phyton Int. J. Exp. Botany. 80:153160.

Diaz-Filho, M.B. 1996. Germination and emergence of Stachytarpheta cayennensis and Ipomoea asarifolia. Planta Daninha, 14(2):118-126.

Fittschen, W.M. 2006. The role of fire and mechanical clearing in the management of Chromolaena odorata. Thesis. University of Kwazulu-Natal, South Africa. http://researchspace,ukzn. ac.za/ispu/handle/ 10413/5492?show=full. Accessed on November 10, 2012. 
Garcia, H., P. Nyiren and L. Desfontaines. 2001. Dynamics of nonstructural carbohydrates and biomass yield in a fodder legume tree at different harvest intensities. Tree Physiology. 21:523-531.

Gautier, L. 1992. Taxonomy and distribution of tropical weed, Chromolaena odorata (L.) R.King and H. Robinson. Candollea. 47:645662.

Gilman, G.F. 2013. Stachytarpheta jamaicensis Blueporter weed. University of Florida IFAS Extension.

Jeffery, M. 2010. Annual Report on Siam weed (Chromolaena odorata) Eradication Program. Queensland Government, Australian Government, Department of Agriculture, Fishery and Forestry, Brisbane.

Landsdale, W.M. and I.L. Miller. 1993. Fire as a management tool for a tropical woody weeds: Mimosa sp in northern Australia. J. Environ. Manage. 39 (2) : 77 - 87.

Manappa, K., V. Jowkin. K.S. Channabasappa and S.V. Kelaginamani, 2010. Use of Eupatorium as surface mulch in cashewnut plantations. Karnataka J. Agric. Sci. 23(2):337 - 338.

McFayden, R.E.C. 2003.Chromolaena odorata in South East Asia and Pacific. Australian J. Entomol. 42:130-134.

Ossom, E., B. Lupupa, S. Mhlongo and L.
Khumalo, 2007. Implication of weed control methods on Sandanezwe (Chromolaena odorata) in Swaziland. World J. Agric. Sci. 3 (6):7004-713.

Paynter, Q. and G. Finlayson, 2003.Integrated management of Mimosa pigra. J. Ecology, 77: 371- 385.

Renrun, W. and X. Xaejun, 2012. Cultural control of Fejicao (Chromolaena odorata (L.) R.M. King and $\mathrm{H}$. Robinson) by planting signal grass (Brachiaria decumbens Stapf) in Southern Yunnan, The People's Republic of China. http://www.ehs.cdu.edu.au/chromolaena /proceedings/second/cultural control of Fejicao (Chromolaena odorata). Accessed on November 12, 2012.

Sajise, P.E., P.K. Palls, N.V. Norcio and J.S. Lales. 1974. Flowering behavior, pattern of growth, and nitrate metabolism in Chromolaena odorata. Phil. Weed Sci. Bull. 1:17-24.

Shelton, M. 2012. Brachiaria decumbens. http:/www.faoorg/ag/AGP/AGPC/doc/Gbase/ data/pf000188.htm. Accessed on November 2, 2012.

Witkowsky, E.T.F. and M. Wilson. 2001. Changes in density, biomass seed production and seed soil bank of non native plant Chromolaena odorata along 15 years chronosequence. Plant Ecology. 152 (1):13-27. 